\title{
Pelatihan Teknik Pemasaran Online Produk Kerajinan Pada Pusat Dakwah Komunitas Muhammadiyah
}

\author{
Wida Purwidianti*, Tri Septin Mujirahayu \\ Fakultas Ekonomi dan Bisnis, Universitas Muhammadiyah Purwokerto \\ email: widapurwidianti@ump.ac.id
}

\begin{abstract}
This article is entitled Training on Marketing Techniques of Handicraft Products at the Muhammadiyah Community Da'wah Center. Craft Product Marketing Technique Training was held on Friday, July 24, 2020 at the preaching center of the Muhammadiyah community in Srirahayu Village, South Purwokerto. The number of participants who took part in the training was 15 people. Training activities are carried out by extension and training methods. The results obtained in this activity are in the form of entrepreneurship materials, online marketing techniques and online marketing media.
\end{abstract}

Keywords: Entrepreneurship,training, marketing techniques, Handicraft Products

\begin{abstract}
Abstrak
Artikel ini berjudul Pelatihan Teknik Pemasaran Produk Kerajinan Pada Pusat Dakwah Komunitas Muhammadiyah. Pelatihan teknik pemasaran dilaksanakan pada hari Jumat tanggal 24 Juli 2020 di Pusat Dakwah Komunitas Muhammadiyah. di Kampung Srirahayu Purwokerto Selatan. Jumlah peserta yang mengikuti pelatihan sebanyak 15 orang. Kegiatan IbM dilaksanakan dengan metode penyuluhan dan pelatihan. Hasil yang diperoleh dalam kegiatan ini berupa materi kewirausahaan, tekhnik pemasaran online dan media pemasaran online.
\end{abstract}

Kata Kunci: kewirausahaan, pelatihan, teknik pemasaran, produk kerajinan tangan

\section{PENDAHULUAN}

Kampung Sri Rahayu merupakan sebuah perkampungan yang termasuk dalam wilayah Kelurahan Karangklesem Kecamatan Purwokerto Selatan. Kampung ini mempunyai paling banyak warga miskin di Kelurahan Karanglesem. Penduduk di Kampung Sri Rahayu mayoritas tidak memiliki keterampilan dan tingkat pendidikan yang rendah [1]. Kampung Sri Rahayu memiliki problem masalah sosial yang kompleks. Sehingga kampung ini lebih populer dengan nama Kampung Dayak [2].

Hasil penelitian [3] menyatakan rentenir menjadi sumber meminjam uang bagi kelompok masyarakat miskin termasuk di Kampung Sri Rahayu. Faktor ekonomi bukan alasan utama ketergantungan pada rentenir. Namun faktor pola pikir atau mindset menjadi faktor utamanya. Masalah ini dapat diatasi dengan keterlibatan banyak pihak, salah satunya adalah melibatkan kelompok masyarakat yang dapat memberikan penyuluhan atau pelatihan.

Universitas Muhammadiyah Purwokerto (UMP) pada bulan Desember 2019 mendirikan Pusat Dakwah Komunitas di Kampung Sri Rahayu. Peluncuran pusat dakwah ini merupakan usaha UMP untuk mendekatkan Muhammadiyah kepada jamaah di Kampung Sri Rahayu (www. UMP.ac.id). 
Pusat Dakwah Komunitas Muhammadiyah ini membina 300 orang yang terdiri dari ibu-ibu, remaja dan anakanak. Dari jumlah yang dibina tersebut, 30 orang merupakan pengrajin kerajinan keset dari kain perca. Setiap hari mampu memproduksi sebanyak 10 buah keset. Pada kegiatan pengabdian pada masyarakat ini akan mengambil mitra para pengrajin keset dari kain perca yang dibina oleh Pusat Dakwah Komunitas Muhamaddiyah.

Produk kerajinan keset dari kain perca ini mempunyai keunikan yaitu bentuk keset yang masih jarang di pasar. Walaupun begitu teknik pemasaran produk ini masih sangat sederhana. Pemasaran produk tersebut sampai saat ini masih menggunakan promosi person to person dan sangat tergantung sekali pemasaran yang dilakukan oleh pembinanya. Teknik pemasaran yang lain belum dimiliki oleh para pengrajin tersebut. Hal ini merupakan salah satu kendala yang dimiliki agar para pengrajin tersebut bisa menjadi wirausaha yang mandiri.

Teknik pemasaran yang paling efektif saat ini adalah menggunakan media online misalnya menggunakan instagram, facebook, youtobe, whatsapps dan sebagainya. Dalam rangka pembuatan media online tersebut maka diperlukan pelatihan untuk mitra agar mampu membuat pemasaran yang menarik.

Beberapa penelitian telah membuktikan teknik pemasaran menggunakan strategi pemasaran online dapat meningkatkan minat pembelian atau meningkatkan penjualan. [4] menyatakan bahwa strategi pemasara online berpengaruh positif terhadap minat beli konsumen. Penelitian [5] juga menunjukkan hasil yang sama bahwa pemasaran online akan berpengaruh terhadap keputusan pembelian.

Selain pengetahuan tekhnik pemasaran yang masih minim, mitra juga membutuhkan pelatihan untuk kewirausahaan. Hasil penelitian [6] menyatakan salah faktor yang dapat meningkatkan daya saing UMKM adalah kemampuan melakukan usaha. Hasil penelitian dari [7] menemukan ada 650 jiwa penduduk Kampung Sri Rahayu dan 429 jiwa mengalami permasalahan kesejahteraan sosial. Salah satu cara untuk mengatasi permasalahan tersebut adalah dengan mengembangkan dan mengaplikasikan pelatihan dan pendampingan kewirausahaan baik oleh pemerintah, dunia usaha, masyarakat, LSM serta perguruan tinggi.

Berdasarkan penjelasan di atas dapat diketahui bahwa tekhnik pemasaran online dapat meningkatkan penjualan produk dan minat beli konsumen. Dalam rangka memecahkan masalah mitra maka kegiatan pengabdian masyarakat ini memberikan pelatihan tentang kewirausahaan dan tekhnik pemasaran online.

\section{METODE PENGABDIAN}

Khalayak sasaran yang menjadi peserta kegiatan pengabdian masyarakat ini adalah ibu-ibu dan bapak-bapak pengrajin kerajinan keset dari kain perca. Khalayak sasaran ini di bawah binaan Pusat Dakwah Komunitas Muhammadiyah.

Ada tiga langkah yang harus dilakukan untuk melaksanakan kegiatan pengabdian masyarakat ini yaitu :

1. melakukan survey awal dan wawancara dengan pembina Pusat Komunitas Dakwah Muhammadiyah. Hasil kegiatan ini dapat memberika gambaran situasi dari mitra pengabdian masyarakat.

2. mempersiapkan materi dan bahan yang diperlukan untuk kegiatan pengabdian masyarakat.

3. melakukan penyuluhan dan pelatihan tentang kewirausahaan dan tehnik pemasaran online. 
Berdasarkan hasil survei awal maka solusi yang ditawarkan dari kegiatan pengabdian masyarakat ini adalah :

1. memberikan penyuluhan dan pelatihan kewirausahaan. Penyuluhan dilakukan satu kali tatap muka dengan materi tentang kewirausahaan. Dengan pemberian materi kewirausahaan diharapkan dapat memotivasi mitra untuk menjadi seorang wirausaha.

2. memberikan pelatihan teknik pemasaran produk kerajinan keset dari kain perca melalui media online. Pelatihan dilakukan dengan memberikan materi teknik pemasaran produk yang diberikan sebanyak satu kali tatap muka. Dalam pertemuan ini mitra akan dilatih untuk teknik pemasaran yang baik misalnya melalui media promosi secara on line.

\section{HASIL DAN PEMBAHASAN}

Kegiatan pengabdian masyarakat ini dilaksanakan pada Hari Jumat, tanggal 24 Juli 2020. Mitra yang dapat menghadiri kegiatan ini sebanyak 15 orang. Mereka merupakan ibu-ibu dan bapak-bapak yang merupakan pembuat kerajinan produk keset dari kain perca.

Penyuluhan dan pelatihan kewirausahaan disampaikan oleh Wida Purwidianti. Materi yang dibahas tentang bagaimana menjadi wirausaha yang sukses di masa pandemi. Mitra diberikan pelatihan tentang bagiamana melakukan inovasi produk. Gambar dibawah ini menunjukkan kegiatan tersebut.

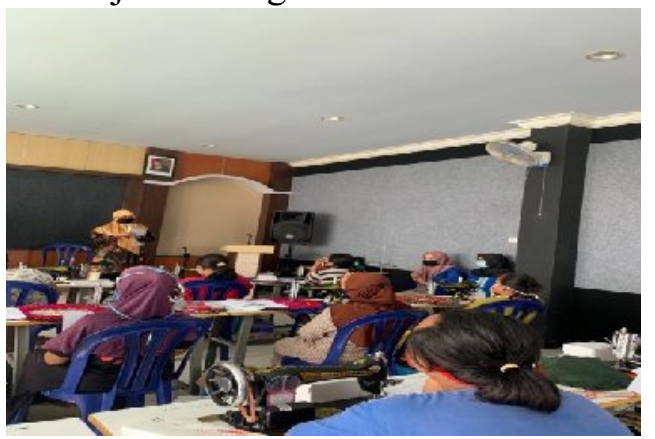

Gambar 1. Penyuluhan dan Pelatihan Kewirausahaan
Selama ini masih mengandalkan pemasaran melalui pembiana atau koordinator Pusat Dakwah Komunitas Muhammadiyah. Pemasaran online belum dilakukan karena kurangnya pengetahuan mitra tentang cara melakukan pemasaran online dan media pemasaran online yang belum dimiliki.

Materi kedua yang diberikan tentang pelatihan tekhnik pemasaran online. Materi ini disampaikan oleh Tri Septin Mujirahayu. Materi yang dibahas tentang kegiatan yang harus dilaksanakan ketika akan melakukan strategi pemasaran online. Kegiatan tersebut meliputi perencanaan, riset produk, menentukan target pasar, menyiapkan merek dan website. Gambar 2 menunjukkan kegiatan pelatihan tekhnik pemasaran online.

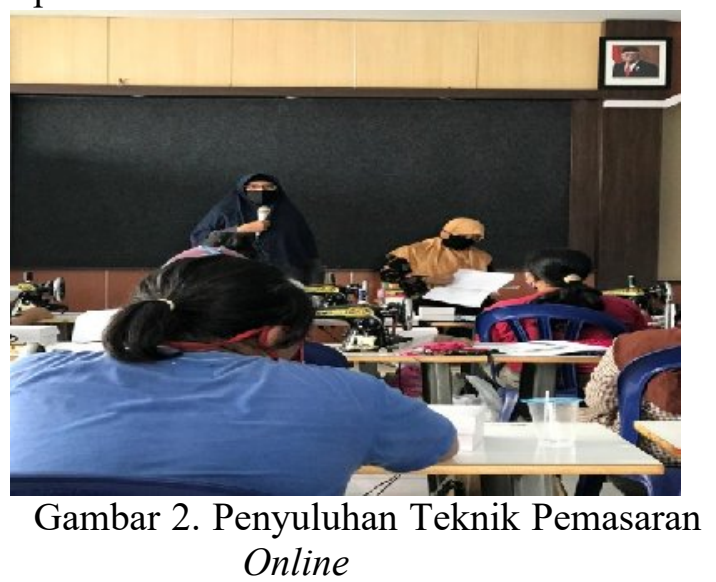

Materi ketiga tentang pelatihan teknik pemasaran online disampaikan oleh mahasiswa-mahasiwa yang membantu kegiatan pengabdian masyarakat ini. Materi yang disampaikan tentang cara membuat katalog produk dan memasarkan nya di media online. Gambar 3 dibawah ini menunjukkan hasil dari pembuatan media pemasaran online. 


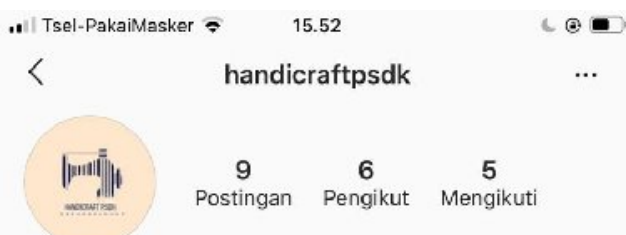

Diikuti oleh satria.project \begin{tabular}{l|l|l} 
Mengikuti & Pesan \\
\hline
\end{tabular} 囲

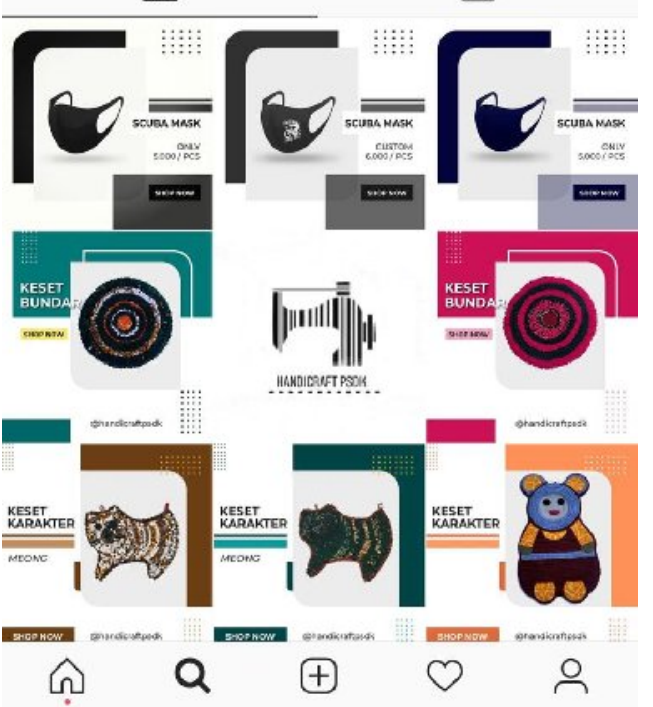

Gambar 3. Media online produk masker dan kerajinan keset dari kain perca

Ada beberapa faktor pendorong dilaksanakannya kegiatan IbM ini yaitu:

1. Kesediaan dan antusiasme mitra dalam mengikuti kegiatan IbM

2. Biaya pemasaran yang murah apabila melakukan promosi secara online.

3. Bisa meningkatkan penghasilan pengrajin keset

Sedangkan faktor penghambat yang ditemukan dalam kegiatan IbM ini adalah sebagai berikut:

1. Motivasi berwirausaha yang masih kurang dari peserta pelatihan

2. Kualitas produk yang masih rendah

\section{SIMPULAN}

Hasil yang dicapai dari kegiatan ini adalah materi kewirausahaan, tekhnik pemasaran dan media promosi online. Saran untuk kegiatan selanjutnya dan tindak lanjut yang harus dilakukan adalah sebagai berikut:

1. Perlu dilakukan pelatihan lanjutan untuk variasi produk kerajinan keset dari kain perca.

2. Perlu adanya sosialisasi dan pelatihan lebih lanjut tentang media promosi online yang lebih bervariasi.

\section{DAFTAR PUSTAKA}

[1] S. S. Mufidah, "Pemberdayaan masyarakat oleh Yayasan Sri Rahayu di Kampung Dayak Kelurahan Karanglesem Purwokerto," J. Univ. Negeri Yogyakarta, 2018.

[2] E. M. Nurhayah, N. Sar, and Avifah, "Peranan Mahasiswa IAIN Purwokerto Dalam Memberdayakan Anak Jalanan Melalui Skema Revolusi Mental dan SDGs Di Kampung Sri Rahayu, Kelurahan Karangklesem, Purwokerto Selatan, Banyumas," Raushan Fikr, vol. 6, no. 2, pp. 273297, 2017.

[3] E. Saepudin and P. D. Cahyani, "Strategi Mempersempit Ruang Gerak Rentenir Melalui Kelompok Masyarakat Berbasis Modal Sosial (Studi Kasus di Kampung Rahayu, Purwokerto)," ISLAMADINA, vol. XVII, no. 2, pp. 57-70, 2016.

[4] W. Jati and H. Yuliansyah, "Pengaruh Strategi Pemasaran Online (online Marketing Strategy) Terhadap Minat Beli Konsumen (Studi Kasus Pada Toko Online Shop Azzam Store)," J. Pemasar. Kompetitif, vol. 1, no. 1, pp. 2598823, 2017.

[5] I. Khoernnikmah and A. Widarko, "Pengaruh Pemasaran Online Terhadap Keputusan Pembelian Konsumen ( studi kasus pada konsumen Toko Sinar Muda Busa)," e-J. Ris. Manaj. PRODI Manaj. Fak. Ekon. Unisma, pp. 
132-147, 2018.

[6] D. C. Lantu, M. S. Triady, A. F. Utami, and A. Ghazali, "Pengembangan Model Peningkatan Daya Saing UMKM di Indonesia: Validasi Kuantitatif Model," vol. 15, no. 1, pp. 77-93, 2016.

[7] Masrukin, "Sebagai Modal Simbolik Masyarakat Banyumas Untuk Mengelola Penanganan Kampung Kumuh ' Sri Rahayu ,", Pros. Semin. Nas. dan Call Pap., vol. 5, no. November, pp. 139-151, 2019. 